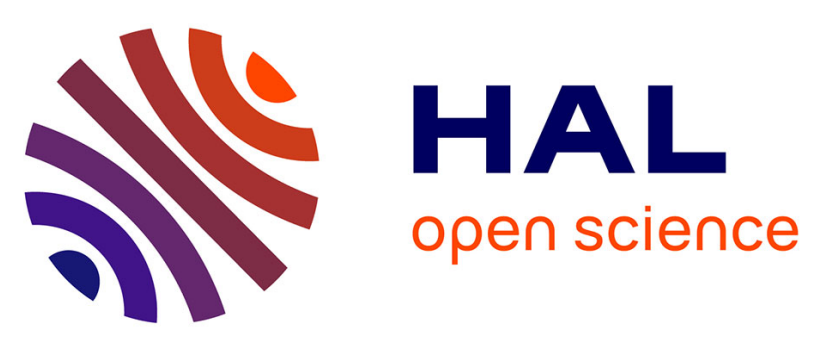

\title{
Insights on Thermal and Fire Hazards of Humins in Support of Their Sustainable Use in Advanced Biorefineries
}

\author{
Anitha Muralidhara, Pierluigi Tosi, Alice Mija, Nicolas Sbirrazzuoli, \\ Christophe Len, Victor Engelen, Ed de Jong, Guy Marlair
}

\section{To cite this version:}

Anitha Muralidhara, Pierluigi Tosi, Alice Mija, Nicolas Sbirrazzuoli, Christophe Len, et al.. Insights on Thermal and Fire Hazards of Humins in Support of Their Sustainable Use in Advanced Biorefineries. ACS Sustainable Chemistry \& Engineering, 2018, 6 (12), pp.16692-16701. 10.1021/acssuschemeng.8b03971 . hal-02355871

\section{HAL Id: hal-02355871 \\ https://hal.science/hal-02355871}

Submitted on 20 May 2020

HAL is a multi-disciplinary open access archive for the deposit and dissemination of scientific research documents, whether they are published or not. The documents may come from teaching and research institutions in France or abroad, or from public or private research centers.
L'archive ouverte pluridisciplinaire HAL, est destinée au dépôt et à la diffusion de documents scientifiques de niveau recherche, publiés ou non, émanant des établissements d'enseignement et de recherche français ou étrangers, des laboratoires publics ou privés. 


\section{Insights on thermal and fire hazards of humins in}

\section{support of their sustainable use in advanced}

\section{biorefineries}

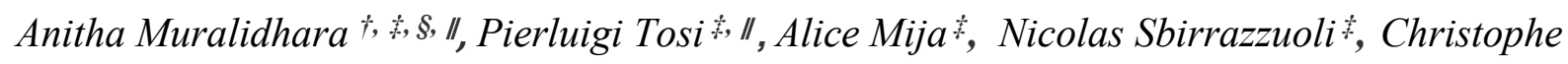
Len \$,\#, Victor Engelen ", Ed de Jong ", and Guy Marlair 广*.

$\uparrow$ Institut national de l'environnement industriel et des risques (INERIS)Parc technologique Alata, BP 2, Verneuil-en-Halatte, Picardie, France,

* Université Côte d'Azur, CNRS, Institut de Chimie de Nice, Parc Valrose, 06108 Nice Cedex

$$
\text { 2, France }
$$

§ Sorbonne Universités, Université de Technologie de Compiègne, Centre de Recherche Royallieu, CS 60 319, F-60203 Compiègne cedex, France

|| Avantium Chemicals B.V., Zekeringstraat 29, 1014 BV Amsterdam, The Netherlands

\# PSL Research University, Chimie ParisTech, CNRS, Institut de Recherche de Chimie Paris, 11 rue Pierre et Marie Curie, F-75231 Paris Cedex 05, France 
KEYWORDS. Humins, thermal and fire hazard analysis, biorefinery, byproducts valorization, calorimetry

(*) corresponding author contact: guy.marlair@,ineris.fr - tel. $+33(0) 344556370$

ABSTRACT. The concept of circular economy is aiming at promoting innovative use of wastes, residues or by-products into marketable chemicals and intermediates, while enhancing process economics and environmental sustainability. Within biorefineries, the focus has now shifted towards "humins", polymeric condensation by-products far less investigated than lignins. Humins are produced in many bio-based value chains that start from polysaccharides pretreatment, targeting access to $\mathrm{C} 6$ and $\mathrm{C} 5$ sugars and further conversion to furanics or levulinics based platform chemicals. They are complex and versatile substrates, and combustible since of organic nature. A first insight on safety issues of humins is therefore proposed in this paper, considering the growing interest on humins as new bio-based feedstocks for various applications. The current study provides characterization details necessary to establish safety information on a global context. This first attempt has brought in preliminary safety data mainly focusing on thermal and fire hazards of humins, to ensure safe storage, handling, transportation and processing. The obtained results show that, overall fire risk of humins so far is similar to the conventional cellulosic fuels such as woody materials. Further consolidation of safety information shall be done with scenario-based risk assessment approach for conditioning safe use of humins in further innovative applications. 


\section{INTRODUCTION.}

Humins are heterogeneous condensation by-products produced by random polymerization processes during the acid catalysed dehydration (ACD) of sugars (Figure 1). ${ }^{1,2}$ Humins formation is known to the scientific community since almost a century through the caramelization process of sugars. Their formation, so far unpreventable, is the principle drawback of ACD process resulting in loss of feed, reactor fouling and other engineering challenges. ${ }^{3,4}$ From a technical viewpoint, three strategies are possible to cope with these challenges linked to production of humins: (a) optimizing the ACD process targeting the minimization of humins production; (b) converting humins into energy to satisfy a substantial part of the energy demand of the biorefinery; (c) integrating humins as a potential valuable carbon source and additional feedstock for new bio-based chemicals, biomaterials or additives of interest. No major breakthroughs were achieved with option (c) ${ }^{5}$ therefore, for a long time, option (b) was the unique industrially applied strategy, while nowadays, despite remaining technical challenges, economic considerations and promising recent research advances ${ }^{6,7}$ justify a move to option (c).

Considering the real industrial scale $\mathrm{ACD}$ of hexoses, humins should be considered more like a mixture. The genuine chemical structure of humins is still under investigation, but seems to be constituted mainly by a furan-rich skeleton containing furfural in an extended conjugated $\mathrm{C}=\mathrm{C}$ network decorated of several functional moieties. ${ }^{8-10}$ Hydroxymethylfurfural (HMF) and derivatives, along with levulinic acid (LA) and other by-products of the ACD process can be present as impurities in the mixture and influence the viscosity. ${ }^{18}$ Humins might possess various reactive functional groups such as aldehyde, ketone, hydroxyl and/or carboxylic. However, other functional groups such as alkoxy and ester can be instigated due to side reactions. ${ }^{4,6,12}$ The 
degree of branching and molecular mass of humins oligomers vary depending on the process and feedstock conditions, with sub-units and structures repeated and connected in a random way. This challenging context has essentially limited industrial uses of humins to energy and/or power conversion through gasification or combustion, however clearly identifying their energy content and combustible nature. ${ }^{13,52,54}$

Some studies have highlighted the potential of humins in catalysis, water purification, energy storage, $\mathrm{CO}_{2}$ sequestration, ${ }^{14-16}$ but also as new bio-based thermosets materials, matrix for impregnations and in producing co-cured composite materials. ${ }^{6,17}$ The last case explores the flame retardancy properties of humins (semi-protective char) that reduces the rate of thermal degradation compared to the normal unsaturated polyesters. ${ }^{18}$ Furthermore, when crude humins are heated to temperature $>180{ }^{\circ} \mathrm{C}$, they can foam into reticulated, rigid macroporous carbon based material. ${ }^{19}$ These foamed humins with versatile potential applications are emerging as a promising alternative in terms of reducing the available quantity of crude humins.

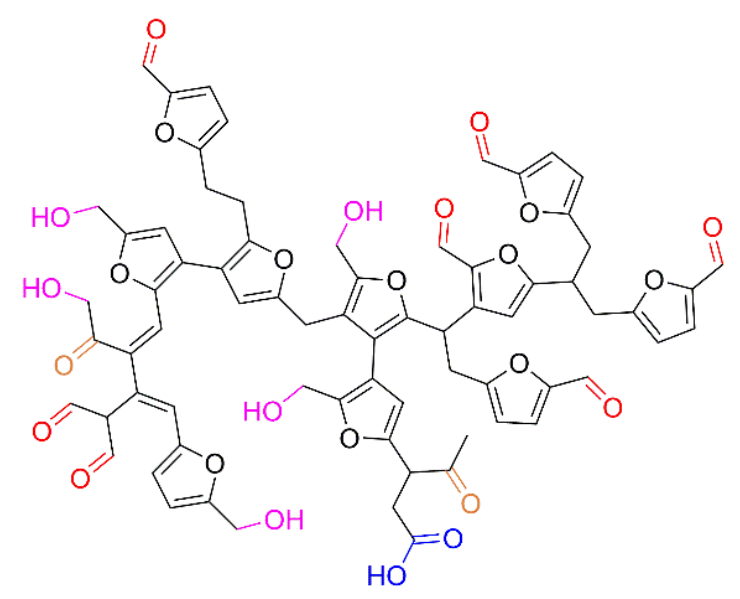

Figure 1. Humins molecular structure model proposed by Van Zandvoort et al. (2013). 
Owing to the complex and versatile chemical structure of humins and subsequent wide variety of physico-chemical properties, the safety profiles, and accordingly the nature and intensity of risks may significantly vary during existing and/or innovative uses.

So far, as a residue used in the production site, Humins' conventional hazards are not recognized by any official hazardous material classification systems quoted in the following references. ${ }^{20-22}$ Neither there is a definite description of their physico-chemical properties (apart from tentative efforts of some production stakeholders), nor consensual information made available regarding precautions requested for their safe handling, use, storage or conversion. One of the main reasons behind this is the lack of complete characterization of humins.

Therefore, as a feedstock of growing interest, both crude and foamed humins (obtained by thermal curing) ${ }^{18,23}$ must be appraised beyond legal requirements more globally in terms of physico-chemical hazards for their safe utilization. Anyway, accessing full characterization of physico-chemical, health and environmental hazards of these products would be a prerequisite for obtaining "end of waste status" according to the EU's waste framework directive. ${ }^{24}$

In addition, due to intrinsic limitations of conventional hazard rating making use of threshold values to fix regulated boundaries, substances or mixtures that are not identified as "dangerous" from hazardous materials classification systems may still induce fire or explosion risks, corrosive or oxidative environments, or trigger some toxic and eco-toxic risks depending on their context of use. ${ }^{25}$ Product and process safety performances must be assessed all along the value chain of humins, not only to take all types of risks (physico-chemical, health and environment) under control, but also to seek competitive advantages. 
Besides addressing the conventional risks, key safety concerns shall also be appraised in humins valorisation routes, 4,6,19,26 which may otherwise lead to an explosive atmosphere (ATEX) under unforeseen circumstance. Examples such as transformation requiring thermal curing of crude humins, handling or transforming foamed humins leading to dust production, pumping crude humins under pressure, impregnation of humins for developing composites, would justify a detailed characterization of fire and explosion hazards (ease of ignition, flammability limits, dust explosion hazard profile, self-heating characteristics and reaction to fire performance of end products).

In addition, thermal stability, hot spot ignition hazard, ${ }^{27}$ speed of combustion, type of surrounding environment, conventional methods of storage and disposal, safety training to the employees, , are some of the governing factors that must also be considered in further evaluation of associated risks during the use and applications of humins.

This is a dedicated research for filling the existing data gaps and developing insights on physico-chemical characteristics of humins and related safety parameters (such as ignitability, flammability or combustible behaviour), that will condition inherently safer and eco-friendly processes for their sustainable valorisation.

\section{MATERIALS AND METHODS}

Humins samples. Crude humins were produced in 2016 in the intermediate step of the FDCA production process in the processing plant of Synvina C.V., ${ }^{27}$ operating in Geleen. They are a high-viscous dark colored material (Figure 2a). The molecular weight of Synvina humins has been reported in another study ranging between 270-650 $\mathrm{g} \mathrm{mol}^{-1} \cdot{ }^{53}$ Foamed humins (Figure 2b) were prepared in a Nabertherm K430/75 dTRON oven under air ventilated conditions, by placing $1 \mathrm{~kg}$ of crude humins in a disposable aluminium pan was heating up to $250{ }^{\circ} \mathrm{C}$ with $5{ }^{\circ} \mathrm{C} \cdot \mathrm{min}^{-1}$ 
ramp, kept to $250{ }^{\circ} \mathrm{C}$ for $1 \mathrm{~h}$, then cooled down to room temperature at $10{ }^{\circ} \mathrm{C} \cdot \mathrm{min}^{-1}$. Mass loss of $\sim 20 \%$ was recorded after treatment of crude humins in such conditions. Elemental composition of both crude and foamed humins was obtained by Inductively Coupled Plasma (ICP) by Mikroanalytisches Labor Pascher, Remagen, Germany.

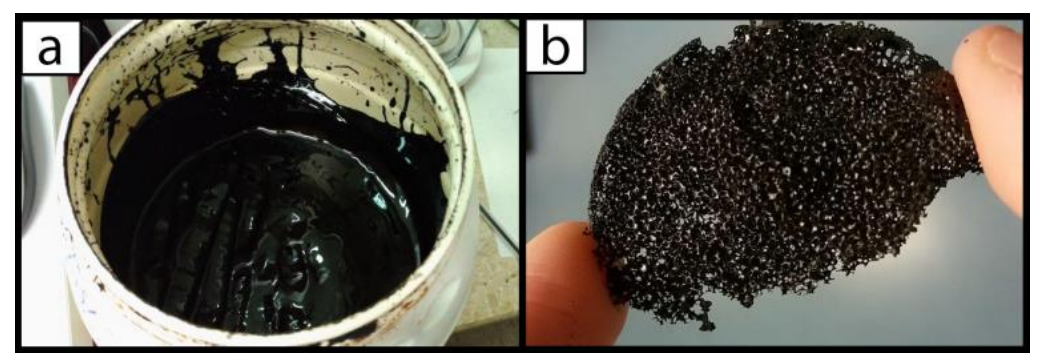

Figure 2. Visual aspect of a) crude and b) foamed humins used in the experiment.

\section{Chromatographic analysis of raw humins.}

GC analyses were performed with a TRACE GC instrument from Interscience, equipped with a FID detector and a column VF WAXms, $0.25 \mathrm{~mm}$ id film thickness $0.25 \mu \mathrm{m}, 30 \mathrm{~m} .1 \mu \mathrm{l}$ of a solution obtained by dissolving humins into a mixture acetonitrile/H2O 50/50 w/w was injected and analysed, while dioxane was used as standard in both calibration and samples.

UPLC analyses were performed with a column from Waters, model Acquity UPLC HSS C18, $2.1 \times 100 \mathrm{~mm}, 1.8 \mu \mathrm{m}$, equipped with UV and ELSD detector and maintained at $50{ }^{\circ} \mathrm{C}$. Sample mass of $3.5 \mu \mathrm{l}$ was injected and analysed using $0.2 \%$ TFA in $\mathrm{H}_{2} \mathrm{O}$ and ACN/MeOH 50/50 (0.4 $\mathrm{mL} \cdot \mathrm{min}^{-1}$ ) as eluents. Saccharine was used as internal standard (measured at $250 \mathrm{~nm}$ )

\section{Differential Scanning Calorimetry (DSC).}


Thermal analysis was performed using the DSC apparatus from SETARAM, model 131 evo, computer controlled by the software Calisto. Temperature and enthalpy calibrations were performed by using indium, tin, lead and zinc standards.

Humins sample of $3.1 \mathrm{mg}$ was prepared upstream and introduced into a high pressure stainless steel crucible of $30 \mu \mathrm{L}$ volume. The crucible was then sealed under air, and introduced into the furnace of the calorimeter along with an empty crucible of the same nature serving as a reference. DSC scans were performed in the temperature range $25{ }^{\circ} \mathrm{C}-500{ }^{\circ} \mathrm{C}$ with a heating ramp of $5^{\circ} \mathrm{C} \cdot \mathrm{min}^{-1}$. A straight baseline has been used for thermograms.

In the result section $T_{\text {start }}$ corresponds to the first integration bond, $T_{\text {reaction }}$ corresponds to the first and last integration bounds and $\mathrm{T}_{\text {onset }}$ corresponds to the slope for the first part of the peak.

\section{C80 (Calvet) Calorimeter.}

C80 CS evo from SETARAM, computer controlled by the software Calisto was used as confirmation test due to its higher sensitivity than standard, first generation DSC.Temperature and enthalpy calibrations were performed by using indium, tin and potassium nitrate. $960 \mathrm{mg}$ of crude humins and $161.8 \mathrm{mg}$ of foamed humins samples were prepared upstream and introduced into a high pressure stainless steel cell, integrating an internal glass crucible. These quantities corresponded to the physical nature of samples with respect to the maximum available volume in the sample holder. Once closed, the crucible was introduced into the furnace of the calorimeter along with an empty crucible of the same nature that is serving as a reference. C80 scans were performed in the temperature range starting from $25^{\circ} \mathrm{C}$ up to $300^{\circ} \mathrm{C}$ using a heating ramp of 1 ${ }^{\circ} \mathrm{C} \cdot \min ^{-1}$. 


\section{Thermo-gravimetric analysis (TGA).}

TGA results were obtained using a Mettler Toledo TGA/SDTD 851e instrument. The microbalance has a precision of $\pm 0.1 \mu \mathrm{g}$ and is kept at constant temperature $\left(\sim 22{ }^{\circ} \mathrm{C}\right)$ during analyses in order to avoid its weight variation with temperature $12 \mathrm{mg}$ of crude humins were placed in $70 \mu \mathrm{L}$ alumina pans. The samples were heated at $10^{\circ} \mathrm{C} \cdot \mathrm{min}^{-1}$ rate in the range $25^{\circ} \mathrm{C}$ $1000{ }^{\circ} \mathrm{C}$ under air and nitrogen gas flow of $80 \mathrm{~mL} \cdot \mathrm{min}^{-1}$ to determine the thermal behavior of humins.

Foamed humins samples were subjected to TGA-DTA (differential thermal analysis) under oxidative environment. This is a purpose-built instrument designed by INERIS (allowing application of test method ASTM E2550) ${ }^{29}$ for further assessing the thermal hazard characteristics of solid samples (Figure 3). An interesting feature of this equipment ${ }^{30}$ is the use of sample mass in the order of $1 \mathrm{~g}$ or more, largely over the classical milligram sample mass used in conventional laboratory scale TGA-DTA commercial instruments. Besides providing both mass loss and thermal decomposition, sample size also allows its use as a screening test for self-heating issues.

Test sample is placed in a small container made from wire mesh; an inert reference substance alumina is placed in an identical container. Both containers are introduced at ambient temperature into an oven and heated at a fixed rate $\left(5^{\circ} \mathrm{C} \cdot \mathrm{min}^{-1}\right)$. 


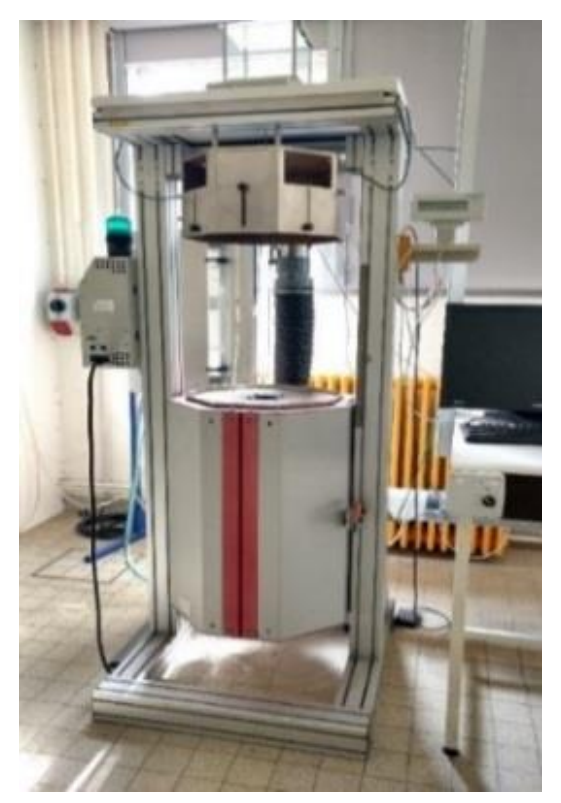

Figure 3. Large scale simultaneous TGA-DTA instrument built at INERIS.

The variation of the mass of the sample is recorded as a function of time with an electronic balance. The temperatures of the sample and of the reference are also recorded as a function of time. An air flow of $440 \mathrm{Nl} \cdot \mathrm{h}^{-1}$ preheated to the oven temperature is maintained. Under these conditions, comparison of sample and reference temperatures shows whether endothermic or exothermic phenomena occurring during the heating in a semi-quantitative way.

\section{Fire Propagation Apparatus (FPA).}

The fire behavior of humins was tested using FPA (Figure 4), commissioned at INERIS in 1997. ${ }^{31-33}$ This apparatus is used as a polyvalent equipment to characterize the fire behavior of various compounds under fire scenarios and associated thermal and chemical risks (e.g. fireinduced toxicity). FPA is covered under various national and international standards, namely FM 4910, NFPA 287, ${ }^{34}$ ASTM E2058, ${ }^{35}$ ISO $12136,{ }^{36}$ and TR $16312 .{ }^{37}$ The apparatus is also known as Tewarson Calorimeter from name of early designer. It is capable of measuring ignitability, fire propagation potential, thermal and chemical characteristics of materials in fire conditions. This is 
a bench-scale multipurpose testing apparatus belonging to the family of fire calorimeters that has proven repeatability and reproducibility performances. ${ }^{38}$

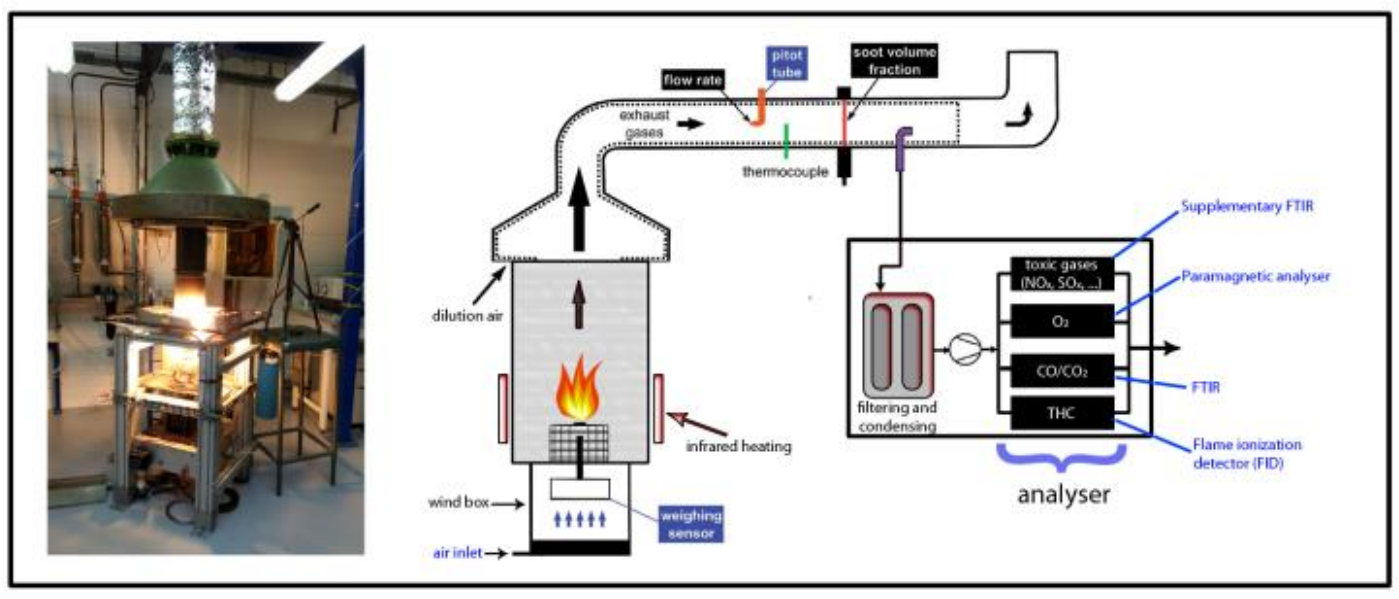

Figure 4. In operation and schematic view of INERIS Fire Propagation Apparatus.

The INERIS FPA is fitted with a Thermo-Fisher Fourier transformer Infra-red (FT-IR) allowing the measurement of many gas species responding in the infrared spectrum. Sample mass of about $20 \mathrm{~g}$ to $40 \mathrm{~g}$ is usually considered for testing chemicals under controlled gas flow in which characterization of test sample (liquids or dense or divided solids) can be made in fuel rich or fuel lean environment to cover the full spectrum of fire conditions (well-ventilated to under-ventilated). Measurements such as mass loss rate, heat release rate, ease of combustion and yields of combustion products for evaluating fire induced toxicity are made by modern fire calorimetry relying of the assessment of Oxygen consumption (OC) or Carbon Dioxide Generation (CDG). ${ }^{39}$ Such measurements give a broader view of the material's response to fire that facilitates a sound scientific diagnosis. Exploration of the full spectrum of ventilation conditions can be done through adjustment of inlet air flow and control of actual ventilation 
conditions through determination of real time equivalence ratio (phi factor) ${ }^{31}$ which reflects actual fuel versus oxygen ratio normalized by same ratio at stoichiometric conditions.

In the present study, preliminary tests were performed to choose the most suitable operating conditions for ignitability and fire propagation in well-ventilated fire conditions. Humins samples of about 20-21 g were placed in a glass sample holder. An external heat flux of 25 $\mathrm{kW} \cdot \mathrm{m}^{-2}$ was set in operation by four infrared heaters housed in air and water cooled jackets, allowing piloted ignition of the sample under calibrated heat stress by use of an electric spark or a pilot flame. Combustion gas analysis was performed by the online FT-IR Spectrometer calibrated over 20 gases for derivation of $\mathrm{CO}_{2}, \mathrm{CO}, \mathrm{SO}_{2}, \mathrm{NOx}, \mathrm{HCN}$, and other species concentrations and relating release rates versus time. In addition, using sample mass loss data, and overall exhaust flow rate measurement, yields of relating emissions may be derived.

\section{RESULTS AND DISCUSSIONS}

Crude and foamed humins underwent thermal stability tests determined by DSC, C80, and TGA, while self-heating tests using TGA/DTA. Qualitative and quantitative reaction-to-fire behaviour (e.g. heat and mass release rates, yields of combustion products, duration of combustion) was examined by Tewarson Calorimeter.

\section{Characterization of humins samples.}

Several batches of industrial humins ${ }^{10}$ were produced via ACD process. Among these, 2 humins samples reflecting the largest variation of observed chemical composition were selected for testing. Along with humins oligomers, an amount of HMF and its alkyl derivatives in these 2 samples have been found between $9 \%$ and $13 \%$. LA was found between $1.2 \%$ and $1.6 \%$. 
The results discussed further are focusing on these 2 samples of crude humins (humins a and humins b) and another first sample of available foamed humins. Therefore, the results obtained should be considered as early information in the field of study that will require statistical consolidations in line with further process optimization.

It is worth mentioning that foamed humins (obtained by subjecting crude humins to a foaming treatment at $250{ }^{\circ} \mathrm{C}$ ) differ significantly both physically and chemically from crude humins as reflected by elemental analysis results (Table 3) with values that are consistent with other humins compositions reported in the literature. ${ }^{12}$ The efficiency of foaming process in terms of carbon mass intensification (17\% increase in carbon mass fraction compared to crude humins) is obtained at the expense of $25 \%$ of hydrogen and $24 \%$ oxygen mass fractions respectively. Thermal curing of crude humins to obtain foamed humins also affects the material's energy content. By using Bioe correlation ${ }^{40}$ to reasonably predict energy values for biomass materials, ${ }^{41}$ the heat of complete combustion increased from $20.2 \mathrm{~kJ} \cdot \mathrm{g}^{-1}$ for crude humins to $23.8 \mathrm{~kJ} \cdot \mathrm{g}^{-1}$ for foamed humins.

\section{Thermal hazard analysis: DSC and C80 calorimetry.}

Crude and foamed humins were subjected to both DSC and C80 analysis and corresponding results were compared (Figure 5a and 5b). For crude humins a wide exothermic thermal event composed of at least two peaks is observed in DSC and C80 starting at around $100{ }^{\circ} \mathrm{C}-125^{\circ} \mathrm{C}$. It ends at around $300{ }^{\circ} \mathrm{C}$ in DSC and at a lower temperature in $\mathrm{C} 80$ which can be explained by the lower heating rate used in this case. This event could correspond to residual crosslinks, selfcondensation or vaporization of monomers and is observed for both DSC and C80. The first event close to $150{ }^{\circ} \mathrm{C}$ is in good agreement with the first mass loss observed in TGA at around $150{ }^{\circ} \mathrm{C}$. Another exothermic thermal event is observed between $300{ }^{\circ} \mathrm{C}-400{ }^{\circ} \mathrm{C}$ in DSC. It 
occurs at higher temperature for Humins b $\left(300{ }^{\circ} \mathrm{C}-400{ }^{\circ} \mathrm{C}\right)$ as compare with Humins a $\left(300{ }^{\circ} \mathrm{C}\right.$ $-350{ }^{\circ} \mathrm{C}$ ). This event is in agreement with the inflexion of the TGA curve observed between 300 and $400{ }^{\circ} \mathrm{C}$. At a temperature higher than $400{ }^{\circ} \mathrm{C}$, the DSC curve shows the starting of increase of the baseline that correspond to the thermal degradation and which is confirmed by the mass loss observed in TGA at this temperature.

Foamed humins showed much less reactivity. The first baseline deviation could correspond to the glass transition, which was confirmed after careful check of calibration tests. An exothermic thermal event is observed at around $150{ }^{\circ} \mathrm{C}$ for both DSC and C80, but ends at much higher temperature for $\mathrm{C} 80$. This could be explained by a higher amount of residual volatilization of organic compounds in C80 because of the higher sample mass and higher free volume in the pan. Thus, the thermal event observed in C80 could be the sum of the two thermal events observed in DSC between $140{ }^{\circ} \mathrm{C}$ and $270{ }^{\circ} \mathrm{C}$, i.e. the first event starting at around $150{ }^{\circ} \mathrm{C}$ and the second one, much lower starting at around $200{ }^{\circ} \mathrm{C}$. Finally, an with a single exothermic peak between

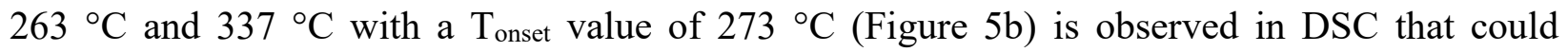
correspond to the beginning of the thermal degradation of the sample.

Table 1. Start and onset temperatures and heats of decomposition of crude and foamed humins determined by DSC experiments.

\begin{tabular}{l|llll} 
Substrate & $\mathbf{T}_{\text {start }}$ & $\begin{array}{l}\mathbf{T}_{\text {reaction }} \\
\left({ }^{\circ} \mathbf{C}\right)\end{array}$ & $\begin{array}{l}\mathbf{T}_{\text {onset }} \\
\left({ }^{\circ} \mathbf{C}\right)\end{array}$ & \begin{tabular}{l}
$\left.{ }^{\circ} \mathbf{C}\right)$ \\
\hline $\mathbf{H}_{\mathbf{d}}\left(\mathbf{J} \cdot \mathbf{g}^{-1}\right)$
\end{tabular} \\
\hline Crude humins a & 143 & $143-352$ & 173 & -505 \\
Crude humins b & 132 & $132-318$ & 165 & -402
\end{tabular}




\begin{tabular}{l|llll} 
Foamed humins & 263 & $263-337$ & 273 & -70
\end{tabular}

For crude humins, in both test methods, i) the decomposition reaction starts earlier due to the volatilization of lower molecular weight compounds and ii) the complexity of reaction mechanisms developing is reflected by the double peaks appearing in the thermogram. 

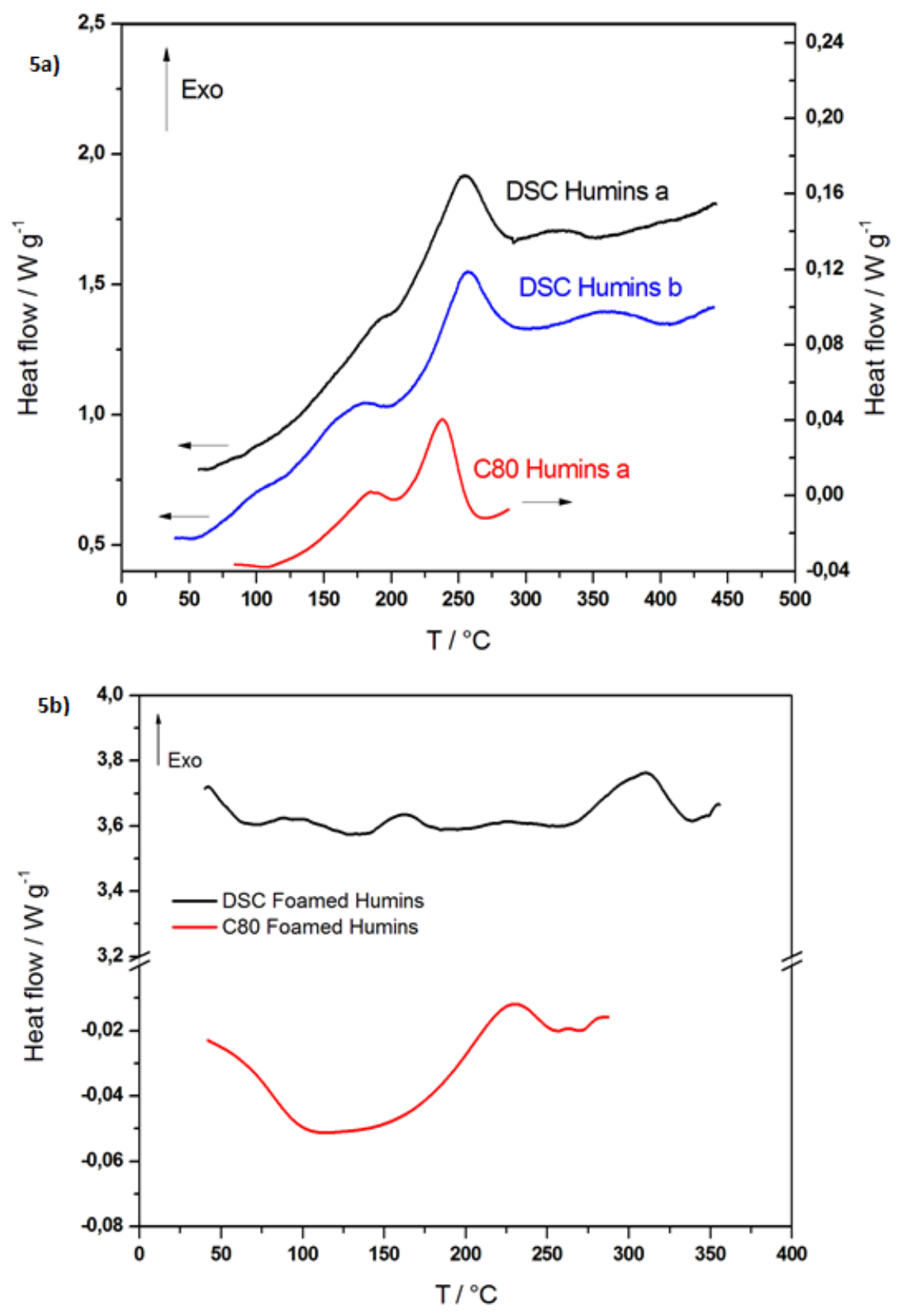

Figure 5. Comparison of DSC and C80 results for a) crude humins and b) foamed humins.

Despite their common origins, the energy levels observed from exothermic decomposition of foamed humins are significantly lower than crude humins. ${ }^{42}$ Foamed humins were initially subjected to thermal curing during their preparation, where they underwent partial 
oxidation/transformation. ${ }^{18}$ This initial thermal curing has contributed to self-crosslinking of humins macromolecules through the functional groups present in humins' structure. These chemical reactions contributed to a better thermal resistance and in turn better thermal stability in foams than crude humins.

For foamed humins, the range of temperature in which thermal decomposition occurs in DSC experiments significantly exceeds the maximum operating temperature explored in C80 (300 $\left.{ }^{\circ} \mathrm{C}\right)$. This does not render a detailed comparison between the DSC and C80 results.

C80 also operates with a larger sample mass and a smaller heat ramp than DSC. It has been observed that, when solid mixtures are studied, sample size has potentially a great influence on results and the question to be addressed is about the homogeneity of samples used from similar batches of available representative samples. ${ }^{43}$ Heterogeneity of samples subjected to different operating conditions might slightly shift the results which are depicted by the slight variation in the range of exothermic peaks in C80 and DSC. Differences in the way pressure may build up in the closed vessels used in the experiment may also be part of the explanation of the observed differences as pressure may affect reaction kinetics. Nevertheless, these variations are not significant and the same was also confirmed during the sample selection.

Thermal stability is not an intrinsic property of any material since apparatus and criteria dependent. As a first statement relating to this aspect, our work allows to conclude that humins thermosets do not entail critical self-heating behaviour. This is an early clearance for storage and transportation of such materials. End use of humins and humins based materials deserve a more detailed evaluation of thermal stability properties depending on the context of use. Similarly, process conditions during the production of crude humins must be considered in further evaluation of thermal stability characteristics. 


\section{TGA and TGA/DTA.}

The profile of thermal stability of crude humins can be observed by the TGA (Figure 6). Three steps of mass loss could be observed under air and only two under $\mathrm{N}_{2}$.

A first mass loss of $\sim 36 \%$ is observed between 120 and $270{ }^{\circ} \mathrm{C}$ in both the conditions, probably due to volatilization of low mass molecules and products of self-condensation. Another mass loss of around $20 \%$ occurs under air in the interval $290{ }^{\circ} \mathrm{C}-400{ }^{\circ} \mathrm{C}$, while is barely present under $\mathrm{N}_{2}(\sim 7 \%)$. A last mass loss of around $45 \%$ leads to the complete thermo-oxidative degradation of humins under air between $400{ }^{\circ} \mathrm{C}$ and $600{ }^{\circ} \mathrm{C}$. Under $\mathrm{N}_{2}$ the mass loss recorded between $400{ }^{\circ} \mathrm{C}-1000{ }^{\circ} \mathrm{C}$ is only around $\sim 22 \%$, giving a final residual product of $\sim 26.3 \%$.

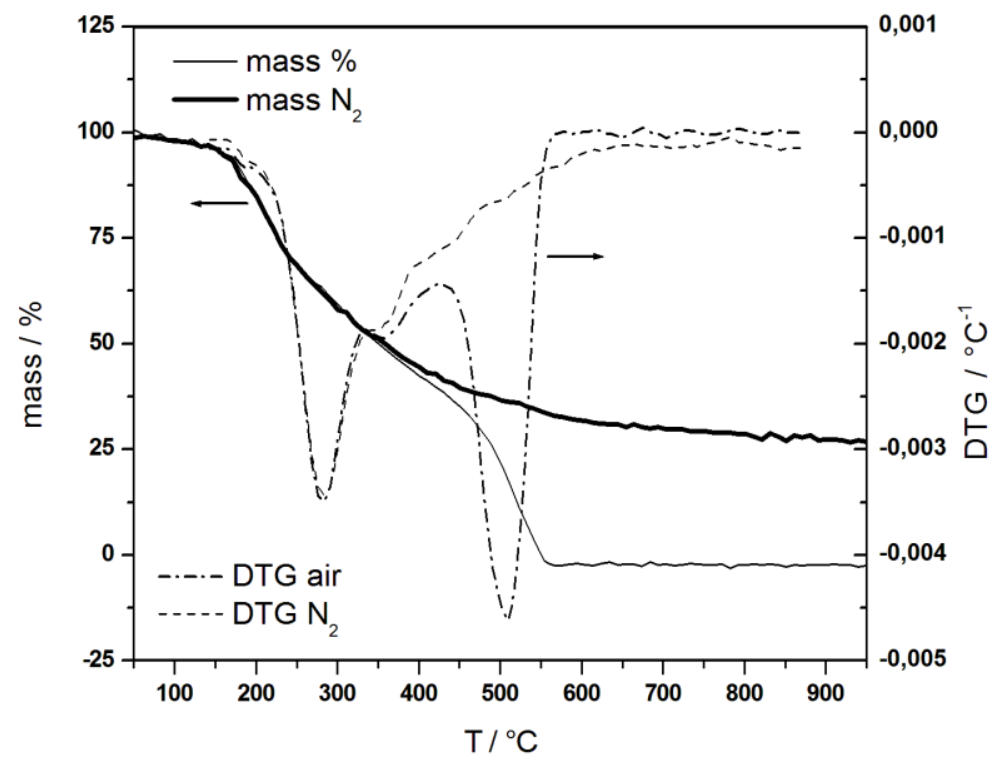

Figure 6. TGA and DTG results for humins in dynamic conditions between 25 and $1000{ }^{\circ} \mathrm{C}$ with a ramp of $10^{\circ} \mathrm{C} \cdot \mathrm{min}^{-1}$. Gas flow: $80 \mathrm{~mL} \cdot \mathrm{min}^{-1}$. 
On the other hand, once formed by thermal curing, foamed humins gain thermal stability in function of the temperature used during their preparation. Foams prepared at $250{ }^{\circ} \mathrm{C}$, for instance, gives a mass loss phenomenon only above $150{ }^{\circ} \mathrm{C}$, with only $10 \%$ of mass loss at 290 ${ }^{\circ} \mathrm{C}$, while thermo-oxidative degradation occurs above $450{ }^{\circ} \mathrm{C}$, possibly leading to ignition We can suppose that if foamed humins are prepared at temperatures higher than $250{ }^{\circ} \mathrm{C}$, all the effects herein observed will result in further delay due to the natural increase in carbon amount.

These results were compared with TGA/DTA measurements of foamed humins samples (Figure 7). Less than $20 \%$ mass loss was observed in the beginning of the reaction up to around $250{ }^{\circ} \mathrm{C}$, followed by the second step of mass loss $(50 \%-60 \%)$ between $250{ }^{\circ} \mathrm{C}$ and $400{ }^{\circ} \mathrm{C}$, and further down foamed humins is almost completely degraded.

In this case, thermal reactivity of the sample is reflected by the measured $\Delta \mathrm{T}$ (the temperature difference between the sample and reference). A critical value of $\Delta \mathrm{T}=50{ }^{\circ} \mathrm{C}$ serves as a first order estimation of a potential self-heating hazard based on former experiences.

According to the test protocol, the material is liable to endure high risk of self-heating if a $\Delta \mathrm{T}$ $=50{ }^{\circ} \mathrm{C}$ is observed at a witness temperature $(\mathrm{WT}) \leq 250{ }^{\circ} \mathrm{C}$. Moderate self-heating risks is considerate to $\Delta \mathrm{T}=50^{\circ} \mathrm{C}$ between $250{ }^{\circ} \mathrm{C}-400{ }^{\circ} \mathrm{C}$ WT, while self-heating risk is absent if $\Delta \mathrm{T}$ $=50{ }^{\circ} \mathrm{C}$ for $\mathrm{WT}>400{ }^{\circ} \mathrm{C}$ (or in case $\Delta \mathrm{T}=50{ }^{\circ} \mathrm{C}$ is never achieved). 


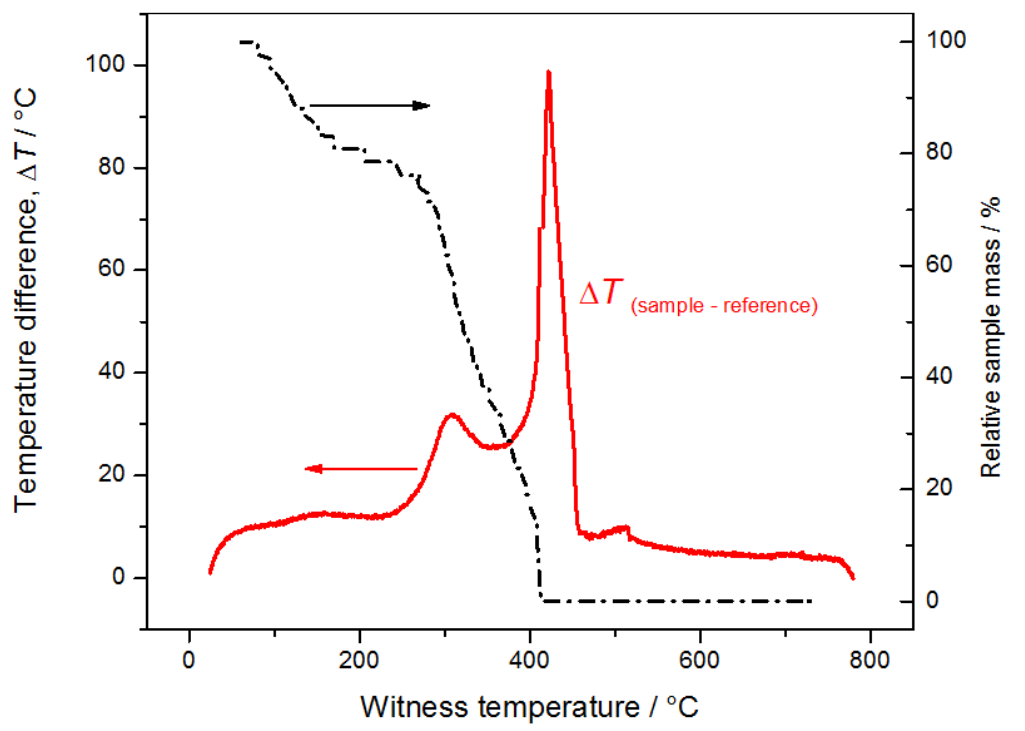

Figure 7. Large scale TGA/DTA results for foamed humins (grey dotted line corresponds to the mass loss profile with its associated scale to the right).

For the foamed humins under investigation, $\Delta \mathrm{T}=50{ }^{\circ} \mathrm{C}$ was observed for $\mathrm{WT}=421{ }^{\circ} \mathrm{C}$, indicating that humins used in the current study doesn't pose any significant risk of self-heating. However, slight variation in the characteristics of humins depending on the process conditions ${ }^{3,4}$ shall be kept in mind. Indeed, the thermal curing required to obtain foamed humins brings better thermal stability in the final material by further diminishing the effect of differences in composition compared to the pristine crude humins.

\section{Fire Risk Analysis.}

Being combustible feedstock by nature - both crude and foamed humins, investigation of their behaviour in fire conditions was performed. The summary of results obtained from FPA test runs and relating overall analysis of mass and thermal balances are presented in Table 2. 
Table 2. Burning behaviour of crude humins and foamed humins in the FPA under wellventilated fire conditions.

\begin{tabular}{llll}
\hline Measured Parameters & $\begin{array}{l}\text { Crude } \\
\text { humins a }\end{array}$ & $\begin{array}{l}\text { Crude } \\
\text { humins b }\end{array}$ & $\begin{array}{l}\text { Foamed } \\
\text { humins }\end{array}$ \\
\hline Sample mass $(\mathrm{g})$ & 20.4 & 20.8 & 12.6 \\
\hline Mass loss $(\%)$ & 66.2 & 65.9 & 75.4 \\
\hline Ignition time (s) & 88 & 75 & 22 \\
\hline Duration of combustion $(\mathrm{s})$ & 236 & 275 & 610 \\
\hline Average mass loss rate $\left(\mathrm{g} \mathrm{m}^{-2} \cdot \mathrm{s}^{-1}\right)$ & 24.6 & 21.5 & 5.8 \\
\hline Max mass loss rate $\left(\mathrm{g} \cdot \mathrm{m}^{-2} \mathrm{~s}^{-1}\right)$ & 35 & 40.8 & 11.9 \\
\hline Phi factor max 44 & 0.19 & 0.22 & 0.16 \\
\hline NHV (from Boie formula in $\left.\mathrm{kJ} \cdot \mathrm{g}^{-1}\right)$ & 20.2 & 20.1 & 23.4 \\
\hline Total energy release $[$ from $\mathrm{CDG}]\left(\mathrm{kJ} \cdot \mathrm{g}^{-1}\right)$ & 14.4 & 14.7 & 17 \\
\hline Energy efficiency conversion $\%$ & 73.5 & 70 & 54.5 \\
$\begin{array}{l}\text { (Boie Correlation) } \\
\text { Carbon mass balance }(\%)\end{array}$ & 95 & 96.3 & 89 \\
\hline
\end{tabular}

\section{Heat of Combustion}

Theoretical heat of combustion value is a basic, very important measurement in any fire safety study. This is the theoretical maximum amount of heat that can be liberated by a product during fire, resulting from complete combustion. When the scientific validation through its actual measurement is unavailable (e.g. from oxygen bomb calorimetry), fairly accurate values of heat of combustion for solid fuels may be calculated using elemental composition of the solid alone 
as unique descriptors of the material, making use of well-known correlations that were initially developed for fossil fuels. ${ }^{45}$

Two different underpinning parameters are generally used to qualify heat of combustion, the Gross or high heating value (HHV) where water vapour condensation latent energy is considered and low or net heating value (NHV) where this change in physical state is not considered. The latter value is generally considered more appropriate in fire studies as a level of the fire location. Water is primarily released as vapour due to fire high temperature.

One such empirical correlation used in this calculation is the Boie equation, which is mentioned below. ${ }^{39,45}$

$\Delta \mathrm{Hc}\left(\mathrm{kJ} \cdot \mathrm{g}^{-1}\right)=35.160 \mathrm{C}+116.225 \mathrm{H}-11.090 \mathrm{O}+6.280 \mathrm{~N}+10.465 \mathrm{~S}$,

where $\mathrm{C}, \mathrm{H}, \mathrm{O}, \mathrm{N}$ and $\mathrm{S}$ are the mass fractions of carbon, hydrogen, oxygen, nitrogen and sulphur in the burning fuel and $\Delta \mathrm{Hc}$ corresponds to HHV.

In addition to humins produced by Synvina C.V., several other humins compositions reported in the literature ${ }^{2,6,46}$ were also considered for calculating $\mathrm{CHC}$ values using Boie formulae. Calculated values are represented in Table 3 together with a few reference materials like heptane, sucrose and ethanol for better understanding of energy intensity of humins and to predict their possible impacts.

Table 3. Compositions and NHV data of humins, ethanol, heptane and sucrose.

\begin{tabular}{l|l|l|l|l}
\hline & $\mathrm{C}$ & $\mathrm{H}$ & $\mathrm{O}$ & $\begin{array}{l}\mathrm{NHV} \\
\Delta \mathrm{Hc}\end{array}$ \\
\hline & mass-\% & mass-\% & mass-\% & $\left(\mathrm{kJ} \cdot \mathrm{g}^{-1}\right)$ \\
\hline Crude humins a* $^{*}$ & 53.4 & 5.9 & 39.7 & 20.2 \\
\hline
\end{tabular}




\begin{tabular}{|c|c|c|c|c|}
\hline Crude humins $b^{*}$ & 53.9 & 5.7 & 39.8 & 20.1 \\
\hline Foamed humins* & 63.1 & 4.5 & 30.9 & 23.4 \\
\hline Humins\# 5 & 60 & 5 & 32 & 23 \\
\hline Humins ${ }^{48}$ & 64.8 & 4.1 & 31.1 & 24.7 \\
\hline 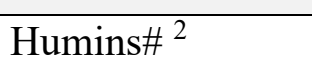 & 66.7 & 3.7 & 29.6 & 23.7 \\
\hline Ethanol & 52.2 & 13 & 34.8 & 26.8 \\
\hline Heptane & 84 & 16 & - & 44.7 \\
\hline Sucrose & 42.1 & 6.4 & 51.5 & 15 \\
\hline
\end{tabular}

* Experimental humins samples

\# Literature humins data

From Table 3 we can observe that, irrespective of the varying origins of humins, the NHV does not vary significantly, with a standard deviation evaluated to be only \pm 1.91 . Irrespective of structural modifications that may result from humins' production modes, the observed differences in overall elemental composition of those carbohydrate derived structures are not leading to significant differences in heat content. We may conclude from this simple analysis that humins would contribute to fire nearly in the same proportion as a dry wood $(\mathrm{HHV}=19.5 \mathrm{~kJ}$ $\left.\mathrm{g}^{-1}\right),{ }^{47}$ and half the proportion of more conventional hydrocarbon fuels in terms of energy release for same mass converted in a fire event. This conclusion cannot reflect any difference in combustion kinetics which is focused in the following section.

\section{Ignition and Heat Release Rate in Fire Conditions.}

Both crude and foamed humins were submitted to piloted ignition in the FPA. Foamed humins presented some resistance to ignition but ignited significantly faster (22 s) than crude humins a and $\mathrm{b}(88 \mathrm{~s}$ and $75 \mathrm{~s})$. The primary reason for this is the higher surface area/volume ratio in foams, where oxygen can more easily react with porous foams on the surface. Crude humins, 
with less surface area/volume ratio and non-porous physical state, takes relatively more time for ignition. Thermal inertia of crude humins is also more important than for foamed humins, which is another potential explanation of differences observed in ignition times.

Once ignited, the crude humins show a rapid increase in heat release rate which is attributing the combustion of lower molecular weight hydrocarbons near the humins-fire interface. After the peak HRR, the rate progressively decreases in 3 steps, as humins tend to swell and form residual porous char. This reflects a shift from early diffusive flaming combustion mode taking place in the gas phase progressively to some heterogeneous combustion process involving the carbonaceous residue forming at the late stages of the studied combustion process. These results are found in correlation with TGA results discussed in the previous section.

Since lower molecular weight volatile compounds are partially or completely oxidized in foamed humins due to the initial thermal curing during their preparation, we may assume that the combustion of foamed humins is likely comparable with final stage of combustion of crude humins. This is shown in second part of the FPA combustion test, where crude humins has already turned to charring material. 


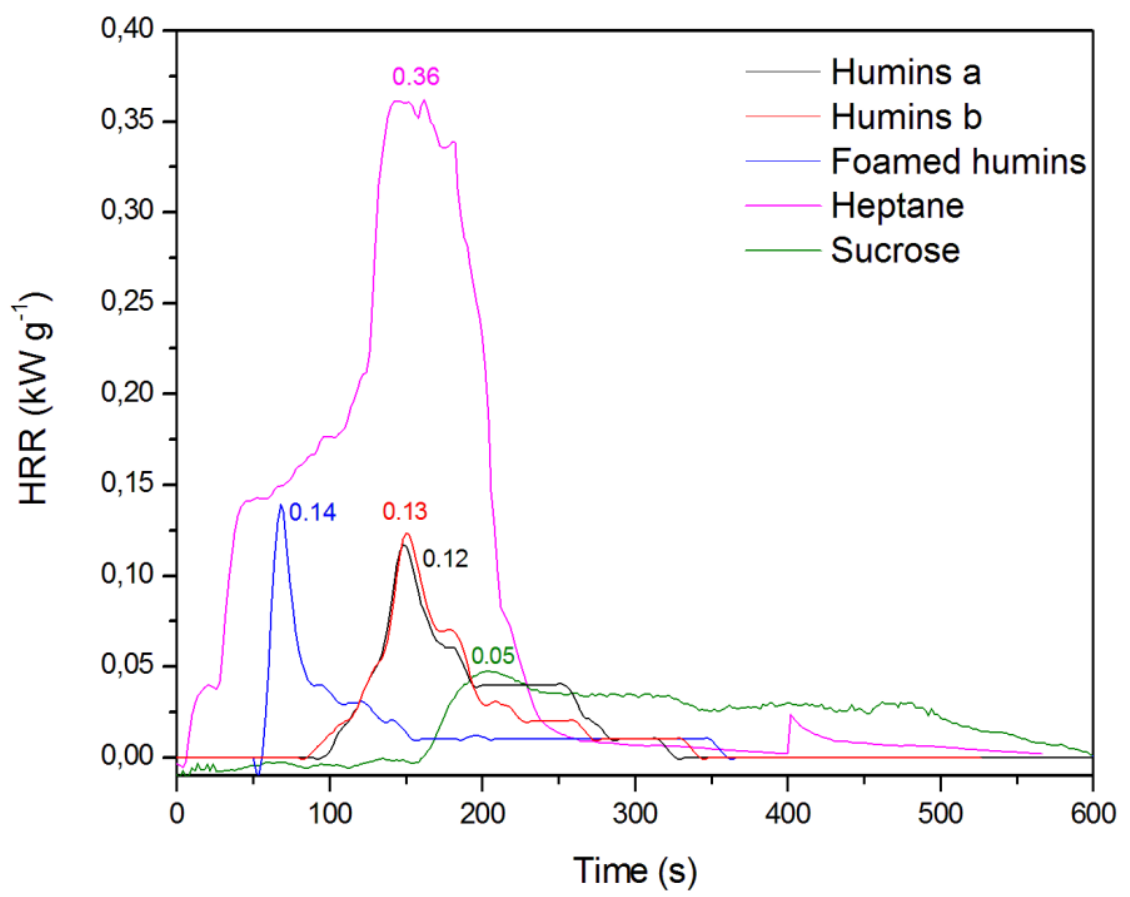

Figure 8. HRR $\left(\mathrm{kW} \cdot \mathrm{g}^{-1}\right)$ profiles of crude humins and foamed humins in comparison with heptane and sucrose as reference materials.

The authors have chosen to present HRR data in some unusual way for fire test performed in pool like configuration (e.g. normalized values per gram of sample burnt and not per sample surface area). This is motivated by the fact that test runs (more marked with foamed humins) led to 3D complex burning mode with progressively undefined surface in combustion by contrast to flammable liquid pools burning in fully diffusive flaming mode in the gas phase (Figure 8).

Peak HRR values per gram burnt of crude humins $a, b$ and foamed humins were found to be $0.12,0.13$ and $0.15 \mathrm{~kW} \cdot \mathrm{g}^{-1}$ respectively, that do not present any significant difference. This is likely to be bound to the fact that flaming combustion process has consumed the major part of 
foamed humins sample, while in the case of crude humins a smaller fraction of the sample was consumed in the initial combustion phase. Although the comparison with heptane is not completely adequate (as comparing solid burning to liquid burning process, we have tried to provide a comparison with a former test, where heptane was burned in the Tewarson apparatus making use of the same size of sample holder, containing nearly the same amount of material $(\sim$ $22 \mathrm{~g}$ ) as crude humins. In such conditions the normalized values of HRR (per unit of mass) was found to be $\sim 67 \%$ lower than heptane for crude humins, and $\sim 59 \%$ lower than heptane for foamed humins, indicating significant lower thermal threats from humins fires compared to heptane fires. However, combustion of humins resulted in significant higher values of HRR (60 $\%$ to $70 \%$ ) than pure disaccharide sucrose in comparable fire conditions.

\section{Yields of major combustion products.}

Considering the elemental composition of humins that is essentially made of $\mathrm{C}, \mathrm{H}, \mathrm{O}$ elements, the major gaseous combustion products expected are carbon oxides $\left(\mathrm{CO}\right.$ and $\left.\mathrm{CO}_{2}\right)$, water vapour and unburned hydrocarbons that can be accounted in terms of total hydrocarbons (THCs).

Release of combustion products in fire is driving the chemical threat, notably in terms of fireinduced toxicity of the fire gases and soot. This has justified the measurement of these combustion products in the FPA experiments with both crude and foamed humins.

Data available so far is reflecting combustion process in well ventilated fire conditions (phi factor $<<1$ ). In these conditions, all carbon available in the crude humins structures would have preferably been converted to $\mathrm{CO}_{2}$, reflected by the higher carbon conversion efficiency $(95 \%)$ than in foamed humins (89\%) (Table 2).

We can further observe from Table 4, a higher CO production in foamed humins than crude humins. This statement simply finds its explanation with an easier mode of oxidation of crude 
humins compared to foamed humins in well ventilated fire conditions, also likely to be related to enhance thermal stability of foamed humins by initial thermal curing. Consistently, incomplete combustion of foamed humins in well-ventilated conditions is also reflected by the production of higher quantities of THC $\left(14.9 \mathrm{mg} \cdot \mathrm{g}^{-1}\right)$. In same combustion conditions, crude humins a and $\mathrm{b}$ release lower amounts of THC $\left(1.9 \mathrm{mg} \cdot \mathrm{g}^{-1}\right.$ and $1.6 \mathrm{mg} \cdot \mathrm{g}^{-1}$ respectively), as their burning process being more efficient and more favourable in gas phase upon their release in the flame.

$\mathrm{CO}_{2}$ is clearly the major combustion product like in any combustion process involving hydrocarbons. As there are rather limited amounts of $\mathrm{CO}$ and soot produced in the test, we might have expected yields of $\mathrm{CO}_{2}$ very close to theoretical maximum values. This is not actually the case due to the charring processes taking place and leaving a significant solid residue in both crude and foamed humins. However, due to significant toxicity of $\mathrm{CO}$ (known responsible of a majority of fire deaths from building fires from decades), it is important to notice that our tests reveal a significant higher conversion efficiency of carbon into $\mathrm{CO}$ in foamed humins under well ventilated fire conditions ( $\sim 15 \%$ of theoretical maximum yield) compared to crude humins in similar fire configurations (less than $1 \%$ ).

Table 4. Yields of combustion products ( $\left.\mathrm{mg} \mathrm{g}^{-1}\right)$ : (a) maximum theoretical yields (b) yields as measured and (c) relating conversion efficiencies (\%) of carbon content into $\mathrm{CO}_{2}, \mathrm{CO}$, hydrocarbon (HC) content into $\mathrm{THC}, \mathrm{CH}_{4}$ and soot from crude and foamed humins.

\begin{tabular}{c|c|c|c|c|c|c|c|c|c}
\hline & \multicolumn{3}{|c|}{ Crude Humins a } & \multicolumn{3}{c|}{ Crude Humins b } & \multicolumn{3}{c}{ Foamed Humins } \\
\cline { 2 - 10 } & $\mathrm{mg} \cdot \mathrm{g}^{-1}$ & $\mathrm{mg} \cdot \mathrm{g}^{-1}$ & $\%$ & $\mathrm{mg} \cdot \mathrm{g}^{-1}$ & $\mathrm{mg} \cdot \mathrm{g}^{-1}$ & $\%$ & $\mathrm{mg} \cdot \mathrm{g}^{-1}$ & $\mathrm{mg} \cdot \mathrm{g}^{-1}$ & $\%$ \\
\hline & $\mathrm{a}$ & $\mathrm{b}$ & $\mathrm{c}$ & $\mathrm{a}$ & $\mathrm{b}$ & $\mathrm{c}$ & $\mathrm{a}$ & $\mathrm{b}$ & $\mathrm{c}$ \\
\hline
\end{tabular}




\begin{tabular}{l|c|c|c|c|c|c|c|c|c}
\hline $\mathrm{CO} 2$ & 1958 & 1404 & 72 & 1976 & 1444 & 73 & 2314 & 1572 & 68 \\
$\mathrm{CO}$ & 1246 & 8.2 & 0.6 & 1257 & 6.8 & 0.5 & 1473 & 216.1 & 14.6 \\
$\mathrm{THC}$ & 593 & 1.9 & 0.3 & 596 & 1.6 & 0.3 & 676 & 14.9 & 2.2 \\
$\mathrm{CH} 4$ & 234 & 1 & 0.4 & 226 & 0.7 & 0.3 & 186 & 11.3 & 6 \\
Soot & $534^{*}$ & 0.8 & 0.14 & 539 & 3.7 & 0.6 & $631^{*}$ & 3.3 & 0.5 \\
\hline
\end{tabular}

*In theoretical estimations, soot is assumed to be pure carbon

** Carbon from the sample also remained in significant quantities of solid residue

\section{Other products of combustion identified from FPA.}

While burning humins in the FPA, production of soot particles was one of the evident observations made both from experiments and visual observations. In a fire, soot is a carbonaceous solid matter produced in a complex way from organic hydrocarbon fragments due to significant incompleteness of combustion process.

Limited quantities of soot (mainly composed of carbon) production was observed in both crude and foamed humins samples (measured yields by optical means were respectively $0.8 \mathrm{mg} \cdot \mathrm{g}^{-1}$ and $3.3 \mathrm{mg} \cdot \mathrm{g}^{-1}$ respectively), showing not surprisingly values far below maximum theoretical yields (see Table 4). Soot is usually produced after the oxidation of burning material into $\mathrm{CO}$ or $\mathrm{CO}_{2}$, in the fuel rich region of the flame through gas-solid interactions. ${ }^{45}$ Indeed, oxygen containing species are rarely leading to significant emission of soot when burning in fire, particularly in well ventilated fire conditions.

\section{Thermal hazard and induced-toxicity from fires involving humins.}

In the current study, heat release rates and yields of major combustion products shaping the overall potential toxicity has been determined. These data can be extrapolated to any well- 
ventilated fire of interest for fire risk assessment purposes by the use of rather classical fire protection engineering techniques, mostly developed and published by ISO TC92 subcommittees $\mathrm{SC}^{48}$ and $\mathrm{SC} 4{ }^{49}$

From the peak value of heat release, the point source model (radiant energy fraction is supposed to dissipate isotropically into a sphere of radius R) can be used to determine the distance $\mathrm{R}$ from the fire source at which a given amount of humins in fire can critically transfer energy by radiation and provoke burns on living organisms or ignite remote combustible materials. ${ }^{50}$

Fire induced toxicity is far more complex,${ }^{51}$ and still leads in some cases to some controversial views between fire toxicity experts. However, data from two immediate previous sections can be used to build up the 'source term' for fire plume dispersion simulations corresponding to a given fire scenario of interest. Certainly, according to the nature and yields of products measured, fire toxicity will not depart significantly to major cellulosic fires (woody materials) and according to our results may essentially drive an actual concern in confined environment. Nevertheless, some precautions shall be also taken in close proximity to fire events in open environment that would involve foamed humins, according to increased trend to convert humins carbon content into CO.

\section{CONCLUSIONS AND PERSPECTIVES}

Until now, industrial humins have been considered as non-hazardous by-product, whilst no rigorous study has been conducted to support this classification. As crude humins are increasingly investigated as new bio-based feedstock for varieties of new applications in advanced biorefineries, no longer restricting its use for in-situ energy conversion, there is a need for clarification on various aspects of humins on a broader perspective. In this direction, this paper is a preliminary attempt to understand the physico-chemical safety concerns such as 
thermal stability, ignitability and combustibility pertaining to humins (both in crude and foamed forms).

Compared to crude humins, foamed humins depicted better thermal stability properties, and do not possess critical self-heating behaviour, although presenting as a highly porous structure.

As all organic compounds, humins are to be considered as combustible materials and they are clearly, relatively easily ignitable under presence of an energetic ignition source. The combustion behaviour of both crude and related foamed humins was further studied, both in terms of heat impact (e.g. energy release) and chemical impact (e.g. yields of combustion products liable to drive the potential fire induced toxicity). From experimental data obtained and by comparison of similar data existing for other well studied fuels, we conclude that the overall fire risk associated with humins does not differ significantly from conventional fires that would involve more conventional cellulosic fuels (e.g. woody materials).

To our knowledge, this work is the first published information about humins focusing on safety issues, an often underscored aspect of sustainable use of new bio-based feedstocks and materials.

As a word of caution, the authors also want to draw attention to the readers that further work is still needed to achieve a more comprehensive insight and understanding of safety issues pertaining to use of humins and humins based derivatives. Indeed, industrial humins can vary in composition depending on their origins, as well as the porosity profile of foamed humins can differ depending on their preparation methods. These aspects cannot be fully accounted in our work. Application of humins and relating processing leading to end-products from such biobased feedstocks might also significantly change the safety side, which was not consider any further in our work . 
AUTHOR INFORMATION

Corresponding Author

*Guy MARLAIR guy.marlair@ineris.fr,_tel: +33(0)344556370

Institut national de l'environnement industriel et des risques (INERIS)

Parc technologique Alata, BP 2, Verneuil-en-Halatte, Picardie, France,

\section{Author Contributions}

The manuscript was written through contributions of all authors. All authors have given approval to the final version of the manuscript. $\uparrow$ These authors contributed equally

\section{Funding Sources}

This work has been funded by the European Commission as part of a H2020 MSCA project named HUGS under the grant agreement \# 675325.

\section{ACKNOWLEDGMENT}

The authors are thankful to Synvina CV for supplying the humins samples required for testing. The authors also acknowledge the support of Mr. Jean-Pierre Bertrand and are thankful for the guidance and support provided while performing experiments with the Fire Propagation Apparatus at INERIS."). The authors gratefully acknowledge the funding support of European Commission as part of a H2020 MSCA project named HUGS under the grant agreement \# 675325. 


\section{ABBREVIATIONS}

ACD, Acid Catalysed Dehydration; TGA/DTA, Thermogravimetric Analysis/Differential Thermal Analysis; FPA, Fire Propagation Apparatus; THC, Total Hydro Carbon; HRR, Heat Release Rate; HHV, High Heating Value; NHV, Net Heating Value; FDCA, Furandicarboxylic acid;

\section{REFERENCES}

(1) Schweizer, A. Caramel and humin. A contribution to the knowledge of the decomposition products of sugars. Recueil des Travaux Chimiques des Pays-Bas 57 (1938), 345-382. DOI:10.1002/recl.19380570402.

(2) Schweizer, A. The Composition of the Humins Produced by the Action of Sulphuric Acid on Some Organic Substances. Recueil des Travaux Chimiques des Pays-Bas 59 (1940), 781-784. DOI:10.1002/recl.19400590814.

(3) van Zandvoort, I.; Koers, E. J.; Weingarth, M.; Bruijnincx, P. C. A.; Baldus, M.; Weckhuysen, B. M. Structural Characterization of 13 C-Enriched Humins and AlkaliTreated 13 C Humins by 2D Solid-State NMR. Green Chem. 2015, 17, 4383-4392.

(4) van Zandvoort, I.; Wang, Y.; Rasrendra, C. B.; Van Eck, E. R. H.; Bruijnincx, P. C. A.; Heeres, H. J.; Weckhuysen, B. M. Formation, Molecular Structure, and Morphology of Humins in Biomass Conversion: Influence of Feedstock and Processing Conditions. ChemSusChem 2013, 6 (9), 1745-1758.

(5) van Putten, R. J.; van der Waal, J. C.; de Jong, E.; Rasrendra, C. B.; Heeres, H. J.; de Vries, J. G. Hydroxymethylfurfural, a Versatile Platform Chemical Made from Renewable Resources. Chem. Rev. 2013, 113 (3), 1499-1597. 
(6) Mija, A.; van der Waal, J. C.; Pin, J.-M.; Guigo, N.; de Jong, E. Humins as Promising Material for Producing Sustainable Carbohydrate-Derived Building Materials. Constr. Build. Mater. 2016, 139, 594-601.

(7) Hoang, T. M. C.; Lefferts, L.; Seshan, K. Valorization of Humin-Based Byproducts from Biomass Processing - A Route to Sustainable Hydrogen. ChemSusChem 2013, 6 (9), $1651-1658$.

(8) Patil, S. K. R.; Lund, C. R. F. Formation and Growth of Humins via Aldol Addition and Condensation during Acid-Catalyzed Conversion of 5-Hydroxymethylfurfural. Energy and Fuels 2011, 25 (10), 4745-4755.

(9) Cheng, Z.; Everhart, J.; Tsilomelekis, G.; Nikolakis, V.; Saha, B.; Vlachos, D. Structural Analysis of Humins Formed in the Brønsted-Catalyzed Dehydration of Fructose. Green Chem. 2018, 20, 997-1006.

(10) Humins, MSDS from producer Synvina CV: Amsterdam, 03-Mar-2017, Personal communication, 2017.

(11) van Zandvoort, I.; van Eck, E. R. H.; de Peinder, P.; Heeres, H. J.; Bruijnincx, P. C. A.; Weckhuysen, B. M. Full, Reactive Solubilization of Humin Byproducts by Alkaline Treatment and Characterization of the Alkali-Treated Humins Formed. ACS Sustain. Chem. Eng. 2015, 3 (3), 533-543.

(12) Kandola, B.; Krishnan, L. Fire Performance Evaluation of Different Resins for Potential Application in Fire Resistant Structural Marine Composites. Fire Safety ScienceProceedings of the $11^{\text {th }}$ Int. Symposium, pp. 769-780 (C) 2014 International Association 
For Fire Safety Science DOI: 10.3801/IAFSS.FSS.11-76

(13) Sevilla, M.; Maciá-Agulló, J. A.; Fuertes, A. B. Hydrothermal Carbonization of Biomass as a Route for the Sequestration of CO2: Chemical and Structural Properties of the Carbonized Products. Biomass and Bioenergy 2011, 35 (7), 3152-3159.

(14) Hu, B.; Wang, K.; Wu, L.; Yu, S.-H.; Antonietti, M.; Titirici, M.-M. Engineering Carbon Materials from the Hydrothermal Carbonization Process of Biomass. Adv. Mater. 2010, 22 (7), 813-828.

(15) Gajic, A.; Koch, H. J.; Marlander, B. HTC-Biochar as a Soil Conditioner - First Results from a Field Trial with Sugar Beet. Zuckerindustrie 2011, 136 (12), 791-799.

(16) Pin, J. M.; Guigo, N.; Mija, A.; Vincent, L.; Sbirrazzuoli, N.; Van Der Waal, J. C.; De Jong, E. Valorization of Biorefinery Side-Stream Products: Combination of Humins with Polyfurfuryl Alcohol for Composite Elaboration. ACS Sustain. Chem. Eng. 2014, 2 (9), 2182-2190.

(17) Kandola, B. K.; Ebdon, J. R.; Chowdhury, K. P. Flame Retardance and Physical Properties of Novel Cured Blends of Unsaturated Polyester and Furan Resins. Polymers, 2015, 7 (2), 298-315.

(18) Tosi, A. P.; Klink, G. P. M. Van; Celzard, A.; Fierro, V.; Vincent, L.; Jong, E. De; Mija, A. Auto-Crosslinked Rigid Foams Derived from Biorefinery by-Products. ChemSusChem 2018, doi.org/10.1002/cssc.201800778.

(19) United Nations, Globally Harmonized System of Classification and Labelling of Chemicals (GHS); sixth revised edition, ST/SG.AC.10/30 Rev6, (c) United Nations, New- 
York \& Geneva, 2015.

(20) ECHA, Guidance on the Application of the CLP Criteria, Guidance to Regulation (EC) No 1272/2008 on classification, labelling and packaging (CLP) of substances and mixtures, European Chemical Agency (ECHA, Eds); ECHA-17-G-21-EN, Cat.Number: ED-02-17-754-EN-N, ISBN: 978-92-9020-050-5, DOI: 10.2823/124801, July 2017.

(21) UN Model Regulations, UN Recommendations on the Transport of Dangerous Goods Model Regulations, Twentieth revised edition. ST/SG/AC10/1/Rev20 (vol1) \& ST/SG/AC10/1 (vol2), C United Nations, New-York \& Geneva, 2017

(22) Mija, A.; de Jong, E.; .van der Waal, J. C.; van Klink, G.; de Jong, E. Humins-Containing Foam, 2017, WO2017074183A1.

.(23) European Commission. Directive 2008/98/EC of the European Parliament and the Council of 19 November 2008 on waste (Waste Framework Directive), Official Journal of European Union, 22 Nov, 2008, L312/3 - L312/30.

(24) Urben, P. G. (Eds), L. Bretherick's Handbook of Reactive Chemical Hazards $7^{\text {th }}$ edition.; Elsevier, Oxford Butterworth-Heinemann, 2006, ISBN 978-0-12-372563-9.

(25) Filiciotto, L.; Balu, A. M.; Van der Waal, J. C.; Luque, R. Catalytic Insights into the Production of Biomass-Derived Side Products Methyl Levulinate, Furfural and Humins. Catal. Today 2016, 302, 2-15..

(26) Field, J. E. Hot Spot Ignition Mechanisms for Explosives. Acc. Chem. Res. 1992, 25 (11), 489-496.

(27) BASF, Business \& Financial News. Synvina: Joint Venture of BASF and Avantium 
Established; Oct 7, 2016, https://www.basf.com/en/company/news-and-media/newsreleases/2016/10/p-16-322.html (accessed Aug 2, 2017).

(28) ASTM E2550-17, Standard Test Method for Thermal Stability by Thermogravimetry, ASTM International, West Conshohocken, PA, 2017

(29) Kwok, Q.; Acheson, B.; Turcotte, R.; Janès, A.; Marlair, G. Thermal Hazards Related to the Use of Potassium and Sodium Methoxides in the Biodiesel Industry. J. Therm. Anal. Calorim. 2013, $111(1), 507-515$.

(30) Brohez, S.; Marlair, G.; Delvosalle, C. Fire Calorimetry Relying on the Use of the Fire Propagation Apparatus. Part I: Early Learning from Use in Europe. Fire Mater. 2006, 30 (2), 131-149.

(31) Brohez, S.; Marlair, G.; Delvosalle, C. Fire Calorimetry Relying on the Use of the Fire Propagation Apparatus. Part II: Burning Characteristics of Selected Chemical Substances under Fuel Rich Conditions. Fire Mater. 2006, 30 (1), 35-50.

(32) Ribière, P.; Grugeon, S.; Morcrette, M.; Boyanov, S.; Laruelle, S.; Marlair, G. Investigation on the Fire-Induced Hazards of Li-Ion Battery Cells by Fire Calorimetry. Energy Environ. Sci. 2012, 5 (1), 5271-5280.

(33) NFPA 287 Standard Test Methods for Measurement of Flammability of Materials in Cleanrooms Using a Fire Propagation Apparatus (FPA), (C) National Fire Protection Association, Quincy, MA. 2017

(34) ASTM E2058-13a, Standard Test Methods for Measurement of Synthetic Polymer Material Flammability Using a Fire Propagation Apparatus ( FPA ), ASTM International, 
West Conshohocken, PA, 2013

(35) British Standards Institution. BS ISO 12136:2011 Reaction to Fire Tests — Measurement of Material Properties Using a Fire Propagation Apparatus. 2011, 1-60.

(36) ISO/TR 16312-2:2007 (Ed1) - Guidance for assessing the validity of physical fire models for obtaining fire effluent toxicity data for fire hazard and risk assessment -- Part 2: Evaluation of individual physical fire models, C ISO, 2007 (34 pages)

(37) Marlair, G.; Tewarson, A. Effects of the Generic Nature of Polymers on Their Fire Behaviour. Proceedings of the 7th International Symposium of Fire Safety Science (Worcester, MA): 2003, 629-642.DOI:10.3801/IAFSS.FSS.7-629

(38) Pretrel, H.; Le Saux, W.; Audouin, L. Determination of the Heat Release Rate of Large Scale Hydrocarbon Pool Fires in Ventilated Compartments. Fire Saf. J. 2013, 62, 192205.

(39) Marlair, G.; Cwiklinski, C.; Tewarson, A. An Analysis of Some Practical Methods for Estimating Heats of Combustion in Fire Safety Studies, Proceedings Interflam'99, Edinburgh, June 1999, UK, (C) Interscience Comm. Ltd,. Un, 1999, 201-212.

(40) Annamalai, K.; Puri, I. K (Eds). Combustion Science and Engineering; CRC Press/Taylor \& Francis, 2007.

(41) Benaissa, W.; Carson, D. Comparison of the results from six calorimeters in the determination of the thermokinetics of a model reaction. AIChE Spring Meeting $2011 \& 7$. Global Congress on Process Safety (GCPS), March 2011, Chicago, United States. AIChE. New York, pp.NC, 2011. 
(42) Liu, H.; Armand, J. Y.; Bouzon, J.; Vergnaud, J. M. Effect of Sample Size and Heating Rate on the DSC Process for Reactions of High Enthalpy. Thermochim. Acta. 1988, 126, $81-92$.

(43) Eshetu, G. G.; Grugeon, S.; Laruelle, S.; Boyanov, S.; Lecocq, A.; Bertrand, J.-P.; Marlair, G. In-Depth Safety-Focused Analysis of Solvents Used in Electrolytes for Large Scale Lithium Ion Batteries. Phys. Chem. Chem. Phys. 2013, 15 (23), 9145-9155.

(44) Diallo, A. O.; Len, C.; Morgan, A. B.; Marlair, G. Revisiting Physico-Chemical Hazards of Ionic Liquids. Sep. Purif. Technol. 2012, 97, 228-234.

(45) Khan M.M., Tewarson A., Chaos M. Combustion Characteristics of Materials and Generation of Fire Products. In: SFPE Handbook of Fire Protection Engineering $5^{\text {th }}$ edition (chapter 36); Hurley M.J. (eds); Springer, New York, NY, 2016, 1143-1232.

(46) Rasrendra, C. B.; Windt, M.; Wang, Y.; Adisasmito, S.; Makertihartha, I. G. B. N.; Van Eck, E. R. H.; Meier, D.; Heeres, H. J. Experimental Studies on the Pyrolysis of Humins from the Acid-Catalysed Dehydration of C6-Sugars. J. Anal. Appl. Pyrolysis 2013, 104, 299-307.

(47) Drysdale, D. (Ed.) An Introduction to Fire Dynamics, $3^{\text {rd }}$ Edition; John Wiley \& Sons, Ltd: Chichester, UK, 2011.

(48) ISO/TC92/SC3. Fire threat to people and environment https://www.iso.org/committee/50540.html (accessed Aug 3, 2017).

(49) ISO/TC92/SC4. Fire safety engineering https://www.iso.org/committee/50552.html (accessed Aug 3, 2017). 
(50) Brohez, S.; Delvosalle, C.; Marlair, G.; Carrau, A. A Zone Model for the Prediction of Thermal and Chemical Effects of a Pool Fire in a Forced Ventilated Enclosure. Proceedings EUROTHERM Conference, Turin, Italy, Oct 2002.

(51) Stec, A. A.; Hull, T. R. (Eds) Fire Toxicity; CRC Press, 2010.

(52) Hoang, T. M.; Lefferts, L.; Seshan, K. Valorization of humin-based byproducts from biomass processing-a route to sustainable hydrogen. ChemSusChem 2013, 6, 1651 - 1658 .

(53) Filiciotto, L; Balu A. M; Romero, A. A; Rodríguez-Castellón, E; van der Waal, J. C; Luque, R. Benign-by-design preparation of humin-based iron oxide catalytic nanocomposites. Green Chem 2017, 19, 4423-4434.

(54) Hoang, T. M. C; van Eck, E. R. H; Bula, W. P; Gardeniers, J. G. E; Leffert, L; Seshan, K. Humin based by-products from biomass processing as a potential carbonaceous source for synthesis gas production. Green Chem 2015, 17, 959-972.

(55) Agarwal, S; van Es, D; Heeres, H. J. Catalytic pyrolysis of recalcitrant, insoluble humin byproducts from C6 sugar biorefinerie. Journal of Analytical and Applied Pyrolysis 2017, $123,134-143$.

\section{Graphical Abtract}




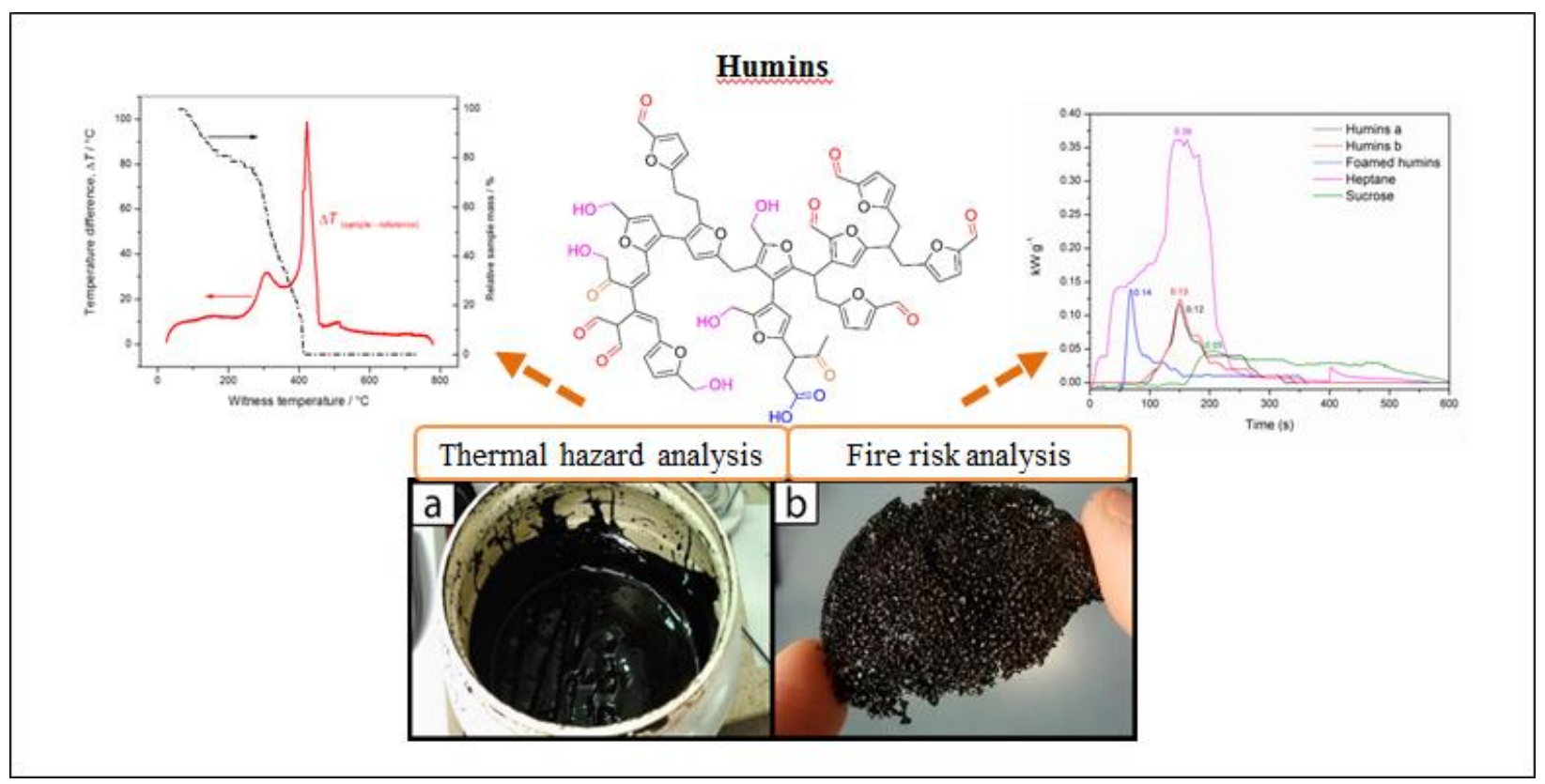

\section{Synopsis:}

Physico-chemical safety profiling of humins is a prerequisite to their multi-dimensional (socio-economic and environmental) sustainable development and applications. 